\title{
AISLAMIENTOS DE HERPES BOVINO DE CASOS CLÍNICOS DEL HOSPITAL DE SALUD ANIMAL DE LA FACULTAD DE CIENCIAS VETERINARIAS
}

\author{
Gollan, A. ${ }^{1}$; Silvano, D. ${ }^{1}$; Occhi, H. ${ }^{1}$; FondeVilla, N. ${ }^{2}$; \\ Juarez, S. ${ }^{1}$; Passeggi, C. ${ }^{1}$; Rodriguez Armesto, R. ${ }^{1}$ \& Piccone, M. e. ${ }^{2}$
}

\section{RESUMEN}

Durante el período comprendido entre el 6-12-02 y el 25-03-04 ingresaron al Hospital de Salud Animal de la Facultad de Ciencias Veterinarias de la Universidad Nacional del Litoral, 63 casos clínicos de bovinos con sintomatología compatible con enfermedades herpéticas. Muestras de órganos de esos casos se procesaron en el laboratorio de Virología del Dpto. de Patología obteniéndose 20 aislamientos virales que fueron identificados como BoHV-1 y BoHV- 5. A partir de órganos de animales de entre 6 y 12 meses de vida con sintomatología nerviosa, se identificaron dos cepas como BoHV-1 y tres como BoHV-5; perteneciendo las restantes 15 cepas recuperadas desde órganos fetales y de bovinos al BoHV-1. Se concluye en la necesidad de contar con sistemas de diagnóstico en fluido funcionamiento para mejorar los conocimientos epidemiológicos de las patologías herpéticas regionales.

Palabras clave: herpes bovino, aislamiento, tipo 1 y 5, abortos.

\section{SUMMARY}

\section{Bovine herpes isolations from clinical cases of the Health Animal Hos- pital}

of the Faculty of Veterinary Sciences UNL

During the period from the 12-06-02 to 03-25-04 there were admitted to the Animal Health Hospital of the Faculty of Veterinary Sciences - Litoral National University - 63 bovine clinical cases with compatible symptoms of diseases caused by herpesvirus. Organs samples of those cases were processed at the Virology Laboratory of the Pathology Department. From them 20 isolations were obtained and were identified as BoHV-1 and 5. From samples of animals among 6 and 12 months with nervous symptomatology, were identified two as BoHV-1 and three as BoHV-5, while from 15 strains recovered from foetal and bovine organs the BoHV- 1 type was identified. We concluded in the need to set a fluid diagnosis system to improve the epidemiological knowledge of the regional herpetic pathologies.

Key words: bovine herpes, isolation, type 1 and 5, abortus.

1.- Cátedra de Virología e Inmunología. Facultad de Ciencias Veterinarias, Universidad Nacional del Litoral. Kreder 2805. Esperanza, provincia de Santa Fe. Subsidio Proyecto 175 Programa 25 CAI+D 2002. UNL.

2.- Instituto de Virología, Centro de Investigaciones en Ciencias Veterinarias, Instituto Nacional de Tecnología Agropecuaria (INTA).

Manuscrito recibido el 31 de agosto de 2009 y aceptado para su publicación el 24 de octubre de 2009. 